\title{
MEASUREMENTS OF THE OUTFLOW ALONG THE EASTERN BORDER OF PLANINSKO POLJE, SLOVENIA
}

\author{
MERITVE ODTOKA NA VZHODNEM ROBU PLANINSKEGA \\ POLJA, SLOVENIJA
}

\author{
Matej BLATNIK ${ }^{1,2}$, Peter FRANTAR ${ }^{3}$, Denis KOSEC $^{3}$ \& Franci GABROVŠEK ${ }^{1,2, *}$
}

\begin{abstract}
UDC 551.435.83:556.16(497.471)
Matej Blatnik, Peter Frantar, Denis Kosec \& Franci Gabrovšek: Measurements of the outflow along the eastern border of Planinsko Polje, Slovenia

Planinsko Polje is the westernmost active polje of Dinaric karst. It is a typical overflow-structural polje, with springs on the southern side feeding the superficial flow of Unica River. The river meanders over the polje towards the terminal outflow area on its northern side, where it sinks back into the aquifer through several ponors. Along the reach in proximity to the eastern border of the polje, the Unica River loses water through several outflow zones into distinct ponors and into a set of small openings and fracture zones. To estimate the outflow rate along these zones, the Unica discharge was measured upstream and downstream to the outflow zone. Seven velocity profiles were recorded with an Acoustic Doppler Current Profiler and the corresponding discharges were calculated. The measurements were taken within four hours during the flow recession following a partial flooding of the Planinsko Polje. Therefore, six outflow zones were evaluated with an outflow rate ranging between $1 \mathrm{~m}^{3} / \mathrm{s}$ and $5.6 \mathrm{~m}^{3} / \mathrm{s}$. The total loss of water along the eastern border summed up to $18 \mathrm{~m}^{3} / \mathrm{s}$ under the given hydrological conditions. These results give new insight into the functioning of karst poljes and provide an important input for eventual future hydrological modelling of the area.

Key words: polje, outflow, ponors, discharge, Acoustic Doppler Current Profiler, Planinsko Polje, Unica.
\end{abstract}

\begin{abstract}
Izvleček UDK 551.435.83:556.16(497.471)
Matej Blatnik, Peter Frantar, Denis Kosec \& Franci Gabrovšek: Meritve odtoka na vzhodnem robu Planinskega polja, Slovenija
\end{abstract}

Planinsko polje je najbolj severozahodno kraško polje v nizu dinarskih polj. Je tipično pretočno-strukturno polje s kraškimi izviri na južni strani, ki napajajo vodotok Unico. Unica preko polja vijuga proti severu, kjer je glavno ponorno območje. $\mathrm{Na}$ poti se tok povsem približa vzhodnemu robu polja, kjer reka izgublja vodo $\mathrm{v}$ več ponornih območjih skozi izrazite požiralnike, nize drobnih odprtin in dobro pretrto kamnino. Za oceno odtoka so bili izmerjeni pretoki Unice gorvodno in dolvodno od teh ponornih območij. Z akustičnim Dopplerjevim merilnikom pretoka je bilo izmerjenih sedem profilov, na podlagi njih pa so bile preračunane vrednosti za posamezno ponorno območje. Štiri ure trajajoče meritve so potekale v času upadanja vode po delno poplavljenem Planinskem polju. $\mathrm{V}$ tem času je imelo šest ponornih območij odtok v vrednosti med $1 \mathrm{~m}^{3} / \mathrm{s}$ in $5.6 \mathrm{~m}^{3} / \mathrm{s}$. V danih hidroloških razmerah je bil skupen odtok $18 \mathrm{~m}^{3} / \mathrm{s}$. Rezultati prispevajo k boljšemu razumevanju delovanja kraških polj in so pomemben vhodni podatek morebitnih hidroloških modelov.

Ključne besede: polje, odtok, ponori, pretok, akustični Dopplerjev merilnik pretoka, Planinsko polje, Unica.

\footnotetext{
1,* Karst Research Institute, ZRC SAZU, Titov trg 2, SI-6230 Postojna, Slovenia, e-mail: mblatnik@zrc-sazu.si, gabrovsek@zrc-sazu.si, * corresponding author

${ }^{2}$ UNESCO Chair on Karst Education, University of Nova Gorica, Glavni trg 8, SI-5271 Vipava, Slovenia

${ }^{3}$ Slovenian Environment Agency, Vojkova 1b, SI-1000 Ljubljana, Slovenia, e-mail: peter.frantar@gov.si, denis.kosec@gmail.com

Received/Prejeto: 15.11 .2016
} 


\section{INTRODUCTION}

Poljes, depressions with a flat bottom, are among the largest karstic geomorphological features. A set of poljes located in the Dinaric karst, stretching from Montenegro on the southeast to Slovenia on the northwest, is a fine example of these features (Ford \& Williams 2007). They have been considered and used as reservoirs for hydropower projects (Milanović 2004; Stevanović \& Milanović 2015) and might be the only areas amid rugged karst terrains suitable for agriculture and settlements. However they are prone to periodical flooding (Kovačič \& Ravbar 2010; Stepišnik et al. 2012), which causes severe damage to infrastructure and concerns to the local population.

The most northwestern active Dinaric polje, Planinsko Polje, belongs to the Ljubljanica River recharge area in southwestern Slovenia (Fig. 1). It is an overflow structural polje (Gams 2004; Ford \& Williams 2007) with springs on one side recharging the Unica River, a typical losing-sinking stream with outflow along the eastern and northern borders of the polje. Planinsko polje starts to be flooded when the Unica recharge surpasses the discharge from the polje. Serious attempts to prevent flooding in Planinsko Polje have been made more than hundred years ago without notable success (Putick 1899; Frantar \& Ulaga 2015). High floods in 2014 (ARSO 2014) caused severe damage to three neighbouring settlements and attracted a wider public attention on these issues (Drole 2015; Frantar \& Ulaga 2015). This opened demands for new research related to the hydrological budget of this polje. Currently, the inflow into the polje is better characterised than its outflow. This work presents the use of an Acoustic Doppler Current Profiler (ADCP) to resolve the question of the outflow rates. To do so, a set of flow velocity profiles were recorded and analysed along the reach of the Unica River adjacent to the eastern line of ponors. The changes of discharge along the reach were interpreted as the amount of water sinking into the adjacent karst massif between the locations of two consecutive profiles.

\section{GEOGRAPHICAL, GEOLOGICAL AND HYDROLOGICAL SETTINGS}

\section{GEOGRAPHICAL POSITION}

Planinsko Polje is located $10 \mathrm{~km}$ northward from the town of Postojna, in the middle of the Notranjska region (Fig. 1). It is the lowest along the set of poljes of the Ljubljanica recharge area and has a total area of about $10 \mathrm{~km}^{2}$ (Gams 2004; Frantar \& Ulaga 2015). Its surface is slightly undulating with elevations ranging between $444.6 \mathrm{~m}$ a.s.l. and $450 \mathrm{~m}$ a.s.l. The polje is mostly used by local inhabitants for pastures and to a lesser extend for field crops (Gams 2004). Three settlements are located on the elevated slopes around the polje, above $455 \mathrm{~m}$ a.s.l. Forested karst plains at elevations between $520 \mathrm{~m}$ and $600 \mathrm{~m}$ a.s.l. and mountains reaching up to $1000 \mathrm{~m}$ a.s.l. surround the polje area (Fig. 1).

\section{GEOLOGICAL SETTINGS}

Planinsko Polje has formed along the Idrija strike-slip fault zone (Fig. 1). Its genesis is tectonically pre-conditioned, but the key mechanism is solutional planation at the piesometric level. The southern and western borders of the polje mostly consist of Upper Triassic Main Dolomite, while major springs are located within a band of Cretaceous limestone on the south. The average thickness of the polje's alluvium cover is about $4 \mathrm{~m}$ and is considered as impermeable (Ravnik 1976). The bedrock base of the polje is dominantly composed of
Upper Triassic Main Dolomite. The eastern and northern borders of polje, which include most of the polje's outflow zones, are composed of highly karstified Cretaceous limestone.

\section{HYDROLOGICAL SETTINGS}

Waters from the mountainous areas of Notranjska region generally flow northwards towards the Ljubljana basin. However, the Idrija fault zone presents a flow barrier, which at the same time deflects general flow direction along the system of Notranjska poljes aligned along the dinaric, southeast-northwest direction. Most of these waters spring at the southern border of the Planinsko Polje, flow over the polje as the Unica River and sink back underground along the polje's eastern and northern borders. The water can be reached in several caves (Fig. 1) located between the polje and the Ljubljanica springs, where all water re-emerges at the border of Ljubljana basin about $12 \mathrm{~km}$ northwest from the polje's ponors.

\section{SPRINGS}

The main spring of the Unica River is Planinska Jama (Planina Cave) with $\mathrm{Q}_{\min }<100 \mathrm{~L} / \mathrm{s}, \mathrm{Q}_{\text {mean }} 14 \mathrm{~m}^{3} / \mathrm{s}, \mathrm{Q}_{\max }>$ $90 \mathrm{~m}^{3} / \mathrm{s}$ (ARSO 2017a). One kilometre east from Planinska Jama is the spring of Malni $\left(\mathrm{Q}_{\text {min }}=1.1 \mathrm{~m}^{3} / \mathrm{s}, \mathrm{Q}_{\text {mean }}=\right.$ $6.7 \mathrm{~m}^{3} / \mathrm{s}, \mathrm{Q}_{\max }=9.9 \mathrm{~m}^{3} / \mathrm{s}$ (Gabrovšek et al. 2010)), which 


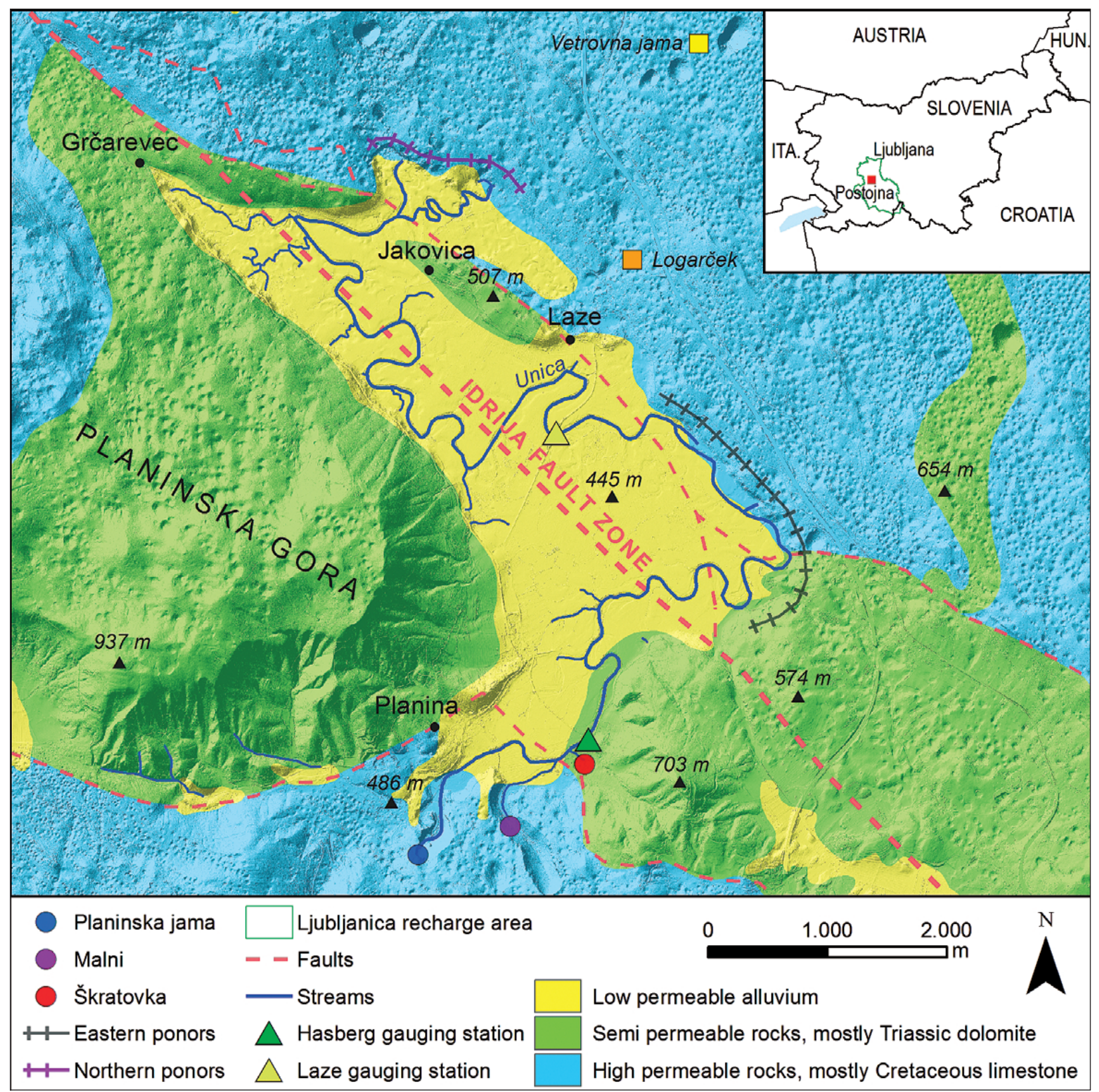

Fig. 1: Planinsko Polje and the surrounding area with the position of caves, springs, ponor areas, gauging stations and main hydrogeological units (modified after Krivic et al. (1976), DEM data from ARSO (2017b)). The upper right insert shows the regional position of the area (red square), where the Ljubljanica recharge area is enclosed by the green line.

is used as a water supply for more than 20,000 inhabitants in the Postojna region.

A set of smaller temporary springs are located east of Malni spring. The biggest among them comes from the Škratovka cave, with an estimated discharge up to $7 \mathrm{~m}^{3} / \mathrm{s}$ during the strongest rain events. All these springs merge to the Unica River $\left(Q_{\min }=1.1 \mathrm{~m}^{3} / \mathrm{s}, Q_{\text {mean }}=21 \mathrm{~m}^{3} / \mathrm{s}, Q_{\text {max }}\right.$ $>100 \mathrm{~m}^{3} / \mathrm{s}$ (Frantar 2008)) and flow through the polje surface for a total length of $17 \mathrm{~km}$. Finally, a set of small higher level temporary and lower level perennial springs located bellow the mountain of Planinska gora on the southwestern and western border of the polje, give rise to several additional contributors to Unica. However, all these tributaries are far downstream from the eastern ponors and do not play role in this study.

\section{FLOODING OF THE POLJE}

Floods in Planinsko polje occur after each intensive rain or snowmelt event (Kovačič \& Ravbar, 2010). The floods usually last from a few weeks to three months. According 

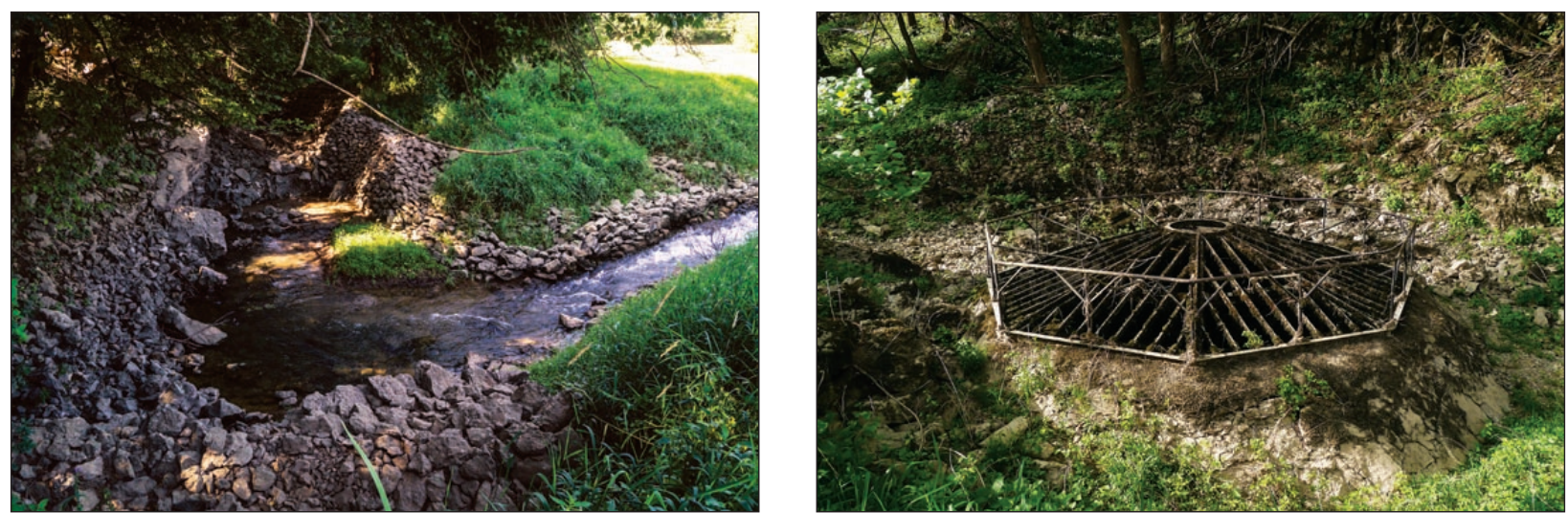

Fig. 2: Example of two ponors found in Planinsko polje. Left: Velike Loke ponors located at the eastern border. Right: So called Putick's Well (Putickova štirna) located at the terminal outflow zone on the northern border (Photos: M. Blatnik).

to Jenko (1959) and Šušteršič (2002), the Unica starts to flood the polje when its discharge surpasses $60 \mathrm{~m}^{3} / \mathrm{s}$ at the Hasberg station. In February 2014, during one of the biggest flood events recorded in the last 100 years, the water level reached $453.2 \mathrm{~m}$ a.s.l. and several houses in the villages of Planina and Laze were partially flooded. The lake covered an area of about $10.3 \mathrm{~km}^{2}$ and nearly 80 million cube meters of water was stored in the polje (Frantar \& Ulaga 2015).

\section{OUTFLOW FROM THE POLJE}

The Unica flows rather uninterrupted over the polje's surface for the first $7 \mathrm{~km}$ (Fig. 1). Along its flow in proximity to the eastern border, it starts losing water along a $2 \mathrm{~km}$ long reach with several groups of ponors and zones of intense leakage. Water sinks into well expressed ponors, along lines of diffuse discharge into fractures and small dissolutional openings and into small blind valleys entrenched into the sediment (Fig. 7). Several studies have addressed the discharge capacity of the eastern group of ponors: $18 \mathrm{~m}^{3} / \mathrm{s}$ (Jenko 1959), $15.1 \mathrm{~m}^{3} / \mathrm{s}$ (Gospodarič \& Habič 1976) and about $20 \mathrm{~m}^{3} / \mathrm{s}$ (Šušteršič 2002). However, the methods used in these studies have not been described.
After $2 \mathrm{~km}$ of flow along the eastern border, the river crosses laterally the polje, and starts to follow the western border for approximately $1 \mathrm{~km}$. Then, it turns northeast towards the second main group of ponors. These ponors are distributed along the northern border of the polje. According to Šušteršič (2002) their outflow capacity is of about $40 \mathrm{~m}^{3} / \mathrm{s}$.

During the beginning of the $20^{\text {th }}$ century, several attempts have been made to increase the outflow capacity of ponors, in order to limit the impact of flooding. Along the polje's northern side a system of wells was constructed (Putick 1899). The wells (latter named after Putick) are few meters in diameter and up to about $10 \mathrm{~m}$ deep, exposing the outflow conduits to the polje surface. They are covered by metal bars to protect their plugging by flotsam (Fig. 2). Along the northern and eastern border, the ponors were also artificially widened and reinforced by concrete to improve their outflow capacity.

Finally, low concrete walls were built along the eastern border to prevent outflow into the ponors during low flow conditions. During medium and high water level, the river flows over these walls into a system of channels, which guide it into the outflow points.

\section{METHODS}

The discharge of the Unica was measured with an Acoustic Doppler Current Profiler (ADCP). The ADCP emits and receives ultrasonic signals to measure water velocity in a specific cross section of the river (profile). The emitted waves are scattered by the small particles (e.g. sediment) moving with the current. The reflected waves are intercepted by the receiver. Due to the Doppler ef- fect, the frequencies of emitted and reflected waves differ according to the relative velocity of the ADCP and the scatterer. Note that in case of reflection the Doppler shift is doubled (Trček \& Cankar 2006; Mueller et al. 2013). The ADCP is fixed to a small vessel called trimaran, which is dragged across the river (Fig. 4). Its speed should be kept constant and small, between 0.2 


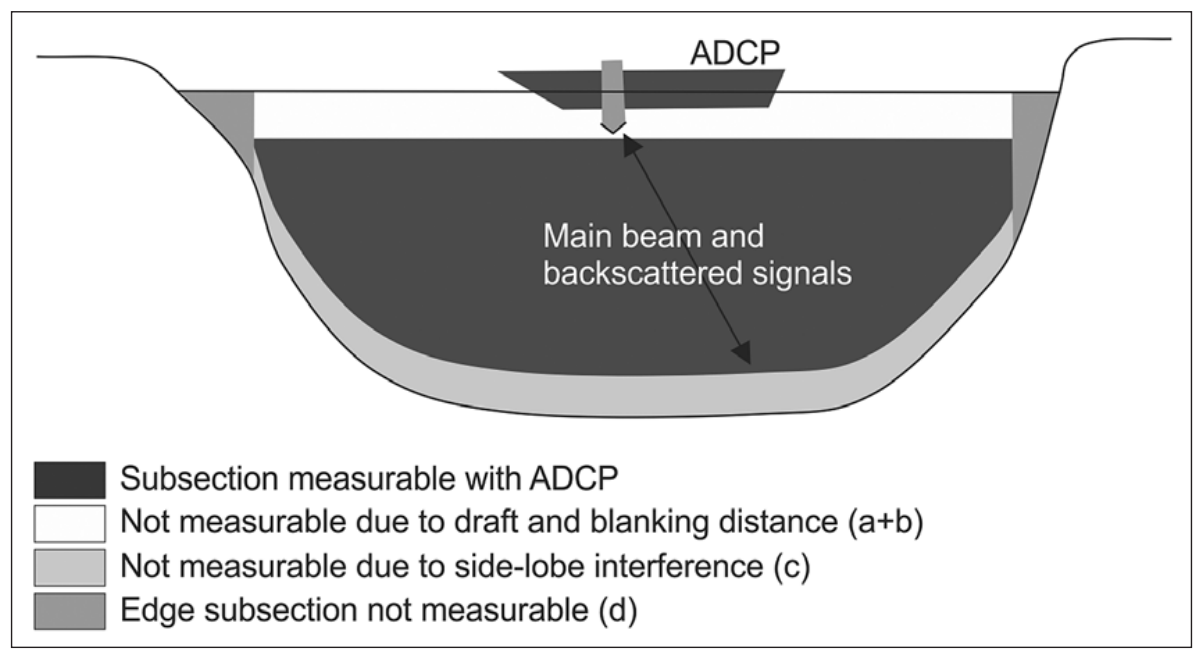

Fig. 3: Sources of potential errors occurring during the ADCP measurements (modified after Mohrlock (1996)).

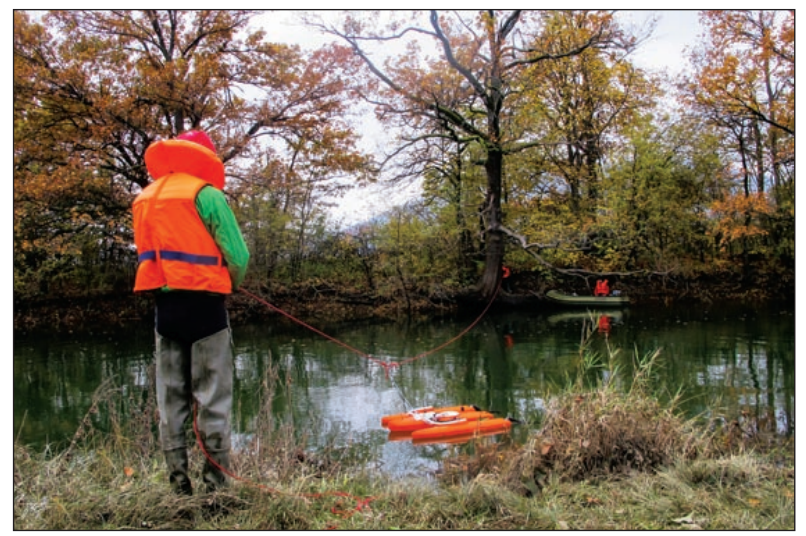

Fig. 4: Trimaran with Doppler radar dragged across the Unica River (Photo: F. Gabrovšek).

$\mathrm{m} / \mathrm{s}$ and $1 \mathrm{~m} / \mathrm{s}$. The obtained velocity field is integrated over the surface of the profile to obtain the discharge. The position of the device is given automatically by the GPS receiver.

Some segments of the profile, such as a narrow band around the flow perimeter cannot be measured correctly (Fig. 3). This is due to:

a) the depth of immersion: the stream velocities above the transducers cannot be measured,

b) the blanking distance: the instrument's physical properties do not allow measurements in near $(\mathrm{few} \mathrm{cm}$ ) proximity of the transducers,

c) side-lobe interference: the reflection of side-lobes from the channel bottom mask the reflection from the scatterers near the bottom,

d) the edge subsections are often inaccessible and therefore not measured correctly.

The discharge in the unmeasured subsections is approximated by extrapolating velocity data from the measured subsections and multiplying this velocity by the unmeasured subsection area (Mohrlock 1996).
In this study, a Teledyne Riverray ADCP device was used. It operates at a $600 \mathrm{kHz}$ frequency and has an ideal depth range between $0.4 \mathrm{~m}$ to $65 \mathrm{~m}$ (Teledyne Instruments 2016). Four beams at 30 degrees angle are used for measuring water velocity. The fifth beam is used for the depth measurement. The ADCP data processing was made with the software WinRiver II. For all profiles various parameters were calculated, including the average discharge that was needed and used in our analysis. Each profile was measured 2-3 times to verify the robustness of the measurements. The range of measurements was within few percent each time.

\section{MEASUREMENT CAMPAIGN}

The measurement period was selected so that the river discharge was small enough for all the water to stay within the Unica streambed (i.e. no flooding of the polje), but high enough to exceed the supposed capacity of the eastern outflow zone.

Between October $13^{\text {th }}$ and $15^{\text {th }} 2015$, over $60 \mathrm{~mm}$ of rain fell over the recharge area. Consequently the discharge of Unica increased from $5 \mathrm{~m}^{3} / \mathrm{s}$ to $67 \mathrm{~m}^{3} / \mathrm{s}$ and Planinsko Polje was flooded. On October $19^{\text {th }}$, additional $18 \mathrm{~mm}$ of rain caused another discharge peak of similar magnitude (Fig. 5), which was followed by the flow recession. The measurements were done on October $27^{\text {th }}$. The total discharge of Unica during the measurement period decreased from $28.4 \mathrm{~m}^{3} / \mathrm{s}$ to $26.1 \mathrm{~m}^{3} / \mathrm{s}$. These two values were recorded with the ADCP device at the Hasberg gauging station. They differ from those of the automatic station, where the discharge dropped from $27.5 \mathrm{~m}^{3} / \mathrm{s}$ to $26.7 \mathrm{~m}^{3} / \mathrm{s}$ within the same time interval (Fig. 6). However, the ADCP measurements are taken as relevant in further calculations and, automatic measurements presented in Figs 5 and 6 are given just to demonstrate the linear trend of decrease.

Seven profiles were recorded along the line of ponors (Fig. 9), starting from the lowermost P7 to the uppermost 


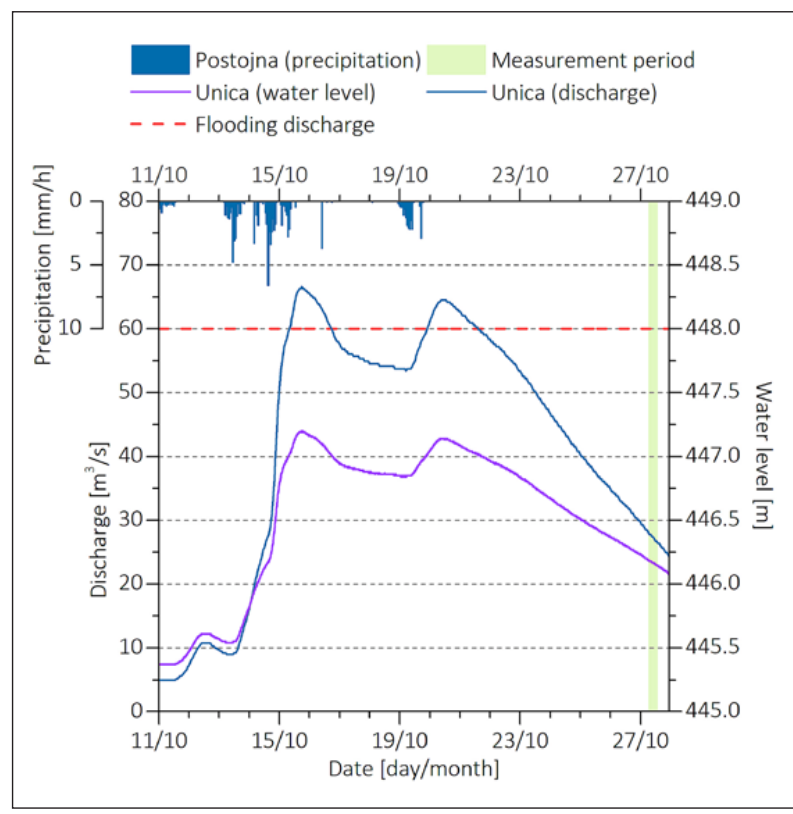

Fig. 5: Water level and discharge from October $11^{\text {th }}$ to $31^{\text {st }} 2015$ recorded at the Hasberg gauging station. The dotted line shows the critical discharge where flooding of the polje begins. The green vertical line marks the measurement period. Hourly precipitation graph is given for the reference.

P1 (Fig. 9, Tab. 1). The profiles were positioned upstream and downstream to the well-known outflow zones in order to characterise their outflow rates. The total duration of measurements was 4 hours and 20 minutes (between 8:35 AM and 12:55 PM). During this period, the total discharge of the Unica at Hasberg station decreased by $2.3 \mathrm{~m}^{3} / \mathrm{s}$. The decrease was almost linear at the rate $\mathrm{R}_{\mathrm{Q}}=$ $8.85 \mathrm{Ls}^{-1} \mathrm{~min}^{-1}$. The profiles were recorded while travelling upstream (from P7 to P1), so that the upper profile $\left(Q_{i-1}\right)$ was always recorded with some delay $\Delta t_{i, i-1}(13 \mathrm{~min}$

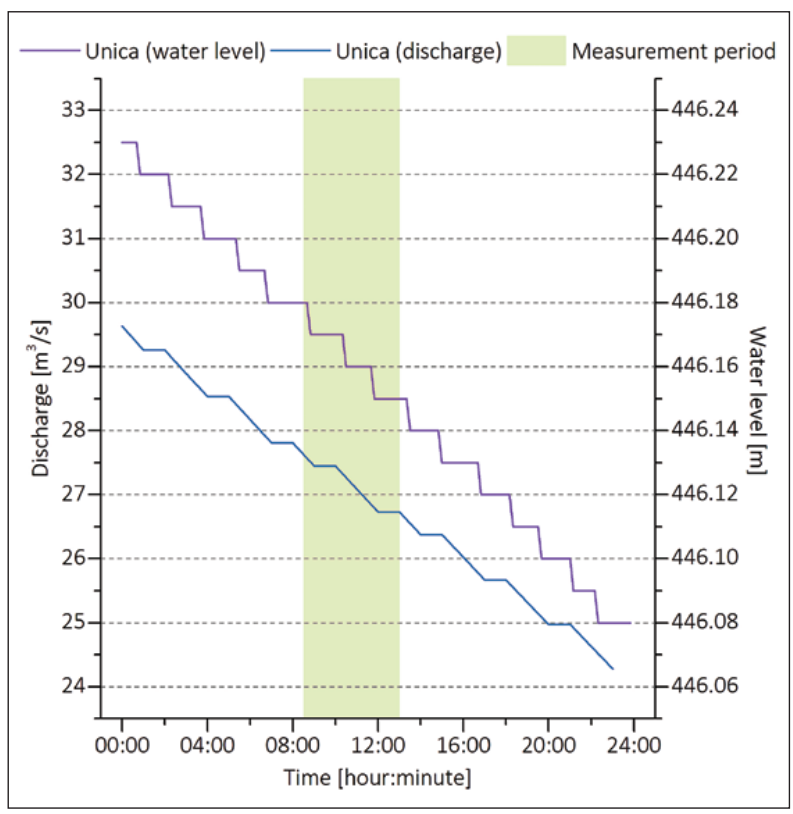

Fig. 6: Water level and discharge on October $27^{\text {th }}$ recorded at the Hasberg gauging station. The green area marks the ADCP's measurement period.

$\leq \Delta_{t, i,-1} \leq 92 \mathrm{~min}$ ) with respect to the lower profile $\left(Q_{i}\right)$. Thus, between two consecutive measurements the total discharge decreased by $R_{Q} \cdot \Delta t_{i, i-1}$. This introduces an underestimation of the outflow rates, if these are taken directly as the difference between the measured discharges $\left(Q_{i-1}-Q_{i}\right)$. To avoid this error, the discharge of the upper profile is corrected for the decrease of total discharge between the two measurements so that $Q_{i-1}^{\text {corr }}=Q_{i-1}+R_{Q} \cdot \Delta t_{i}$ and the outflow within the section $\mathrm{i} \rightarrow \mathrm{i}-1$ is given by $Q_{i, i-1}=Q_{i-1}^{\text {corr }}-Q_{i}$. Results are summarized in Tab. 1 and described in the following paragraph.

\section{RESULTS}

At 8:35 the discharge recorded at Hasberg was $28.4 \mathrm{~m}^{3} / \mathrm{s}$, of which $16 \mathrm{~m}^{3} / \mathrm{s}$ coming from Planinska Jama contributed to Unica, the rest being from Malni and other springs (mostly Škratovka). At 12:55, the total discharge recorded at Hasberg was $26.1 \mathrm{~m}^{3} / \mathrm{s}$. As mentioned before, the values recorded by ADCP measurements are used in all calculations (see Tab. 1 \& Fig. 8).

$P 1$ - P2: At "Mrčonovi ključi", between P1 and P2 the Unica first approaches the border of the polje (Fig. 7 $\& 9$ ). There are no evident ponors or fractures along the line, however the outflow recorded between P1 and P2 was $1.7 \mathrm{~m}^{3} / \mathrm{s}$.
P2 - P3: Between P2 and P3 ("Milavčevi ključi”) the river leaks through two extended fractured zones, respectively $50 \mathrm{~m}$ and $120 \mathrm{~m}$ long, where the water flows directly from the river bed into the fracture zone of the adjacent karst massif (Fig. 7). Between these zones, a concrete embankment prevents outflow during low stage. However, during high stage, the overflow is guided along the lateral trenches into several distinct openings, which act as ponors. During the measurement period, all known ponors were active and the total outflow between P2 and P3 summed up to $5.6 \mathrm{~m}^{3} / \mathrm{s}$. 


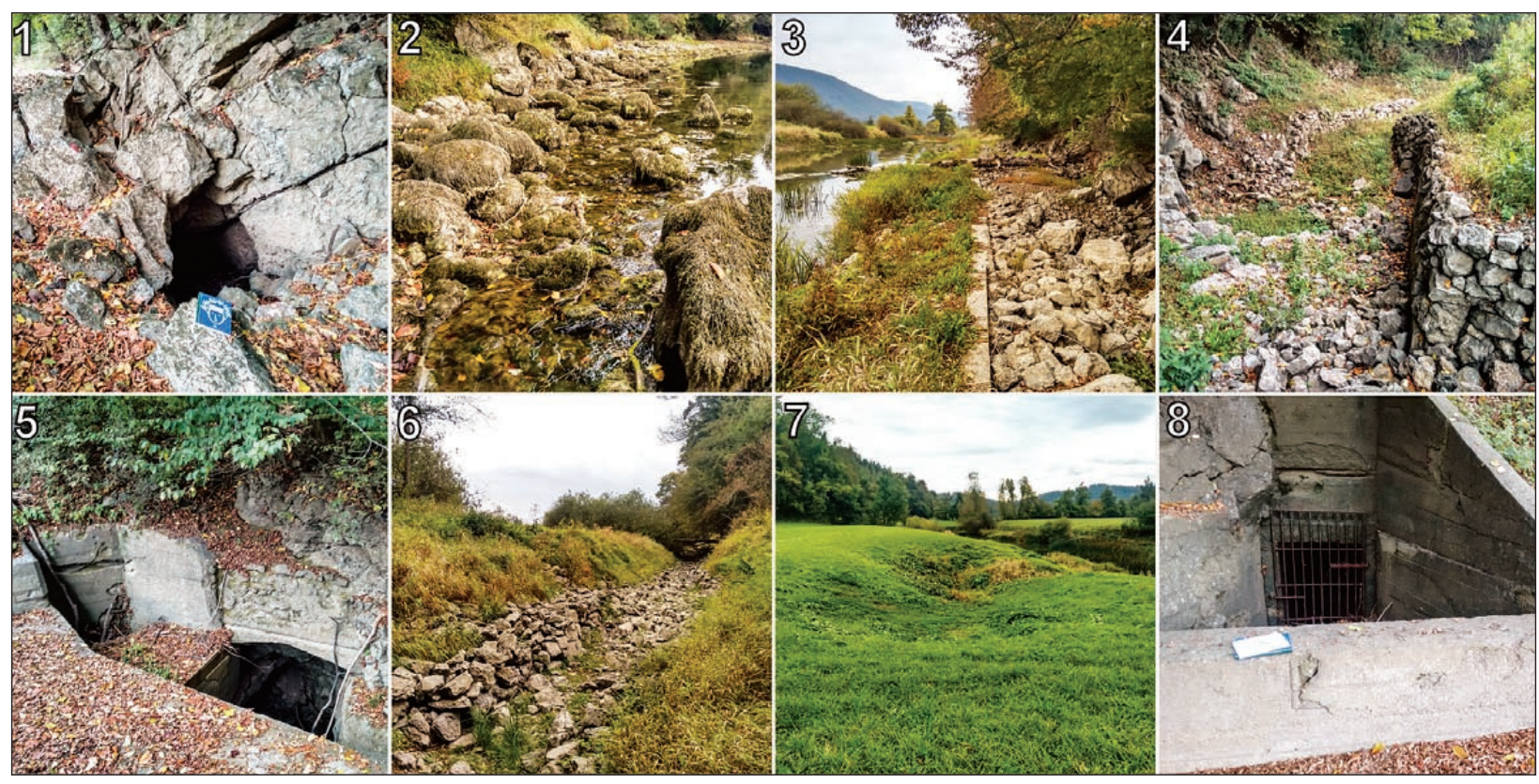

Fig. 7: Outflow features along the eastern border of Planinsko Polje at low water in October 2016. 1) Small ponor at Milavčevi ključi (P2 - P3). 2) Broad outflow zone at Milavčevi ključi (P2 - P3). 3) Concrete embankment and lateral trench along the Unica channel at Ribce (P3 - P4). 4) Trench leading to enlarged fractures and small ponors at Ribce (P3 - P4). 5) Enlarged and reinforced ponors at Ribce (P3 - P4). 6) A channel leading to ponors at Velike loke (P4 - P5). 7) Small channel leading to a sinking point below the alluvium (P5 - P6). 8) Entrance to "Jama v Dolenjih lokah", a 170 m long ponor cave between P6 and P7 (Photos: F. Gabrovšek).

P3 - P4: The $350 \mathrm{~m}$ long reach "Ribce" between P3 and $\mathrm{P} 4$ is characterized by numerous ponors and diffuse outflow zones. The river is mostly embanked during low flow conditions, whereas overflow is again guided to distinct ponors via lateral trenches (Fig. 7) during higher water-levels. Some ponors are artificially enlarged with

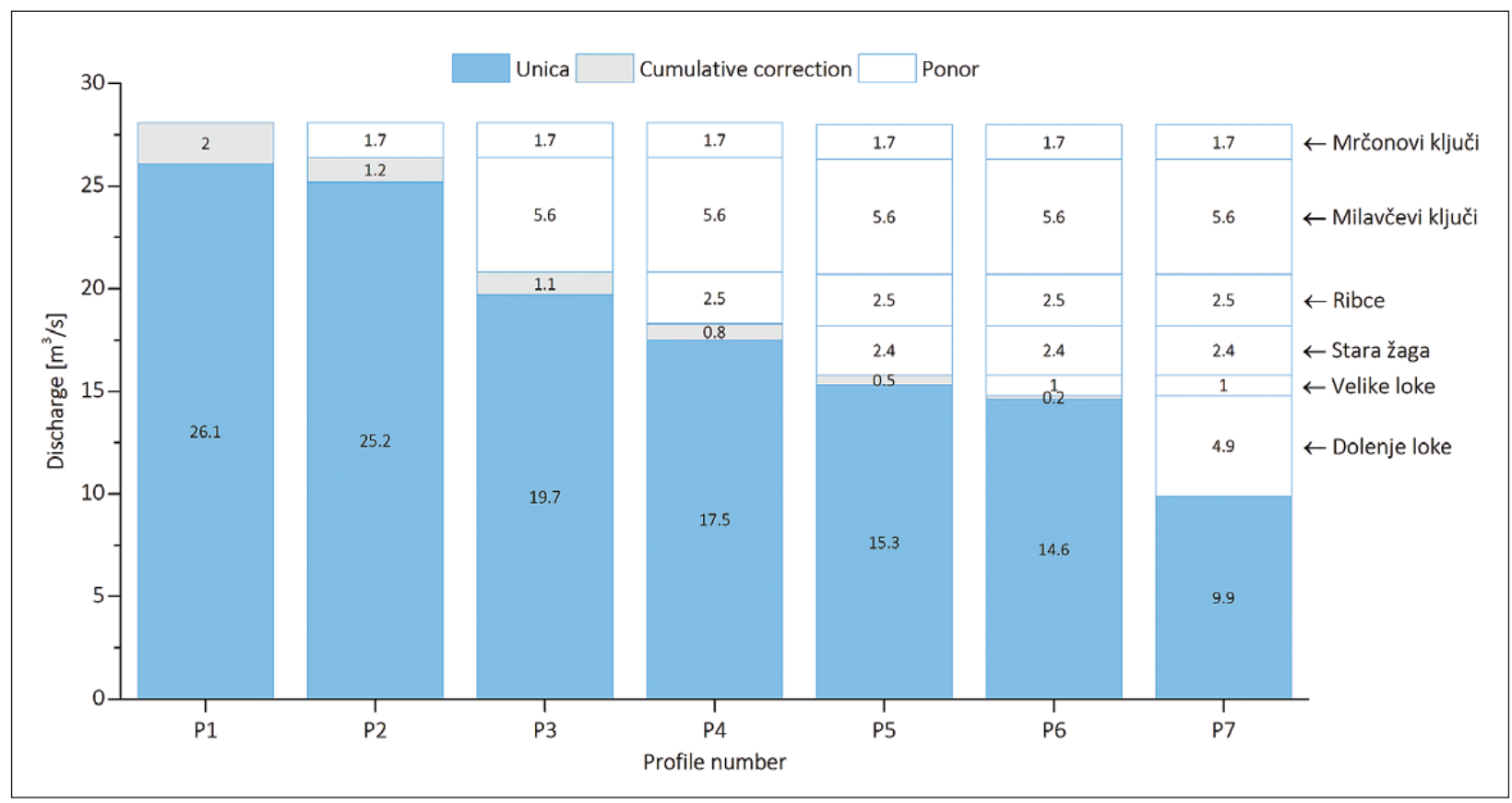

Fig. 8: Discharge of the Unica River along the eastern border of Planinsko Polje. Blue areas denote the measured discharges, grey areas the cumulative corrections due to the linear decrease of Unica discharge from the start of measurements, white areas show the outflows from each zone. Local names of the outflow zones are shown on the right. 


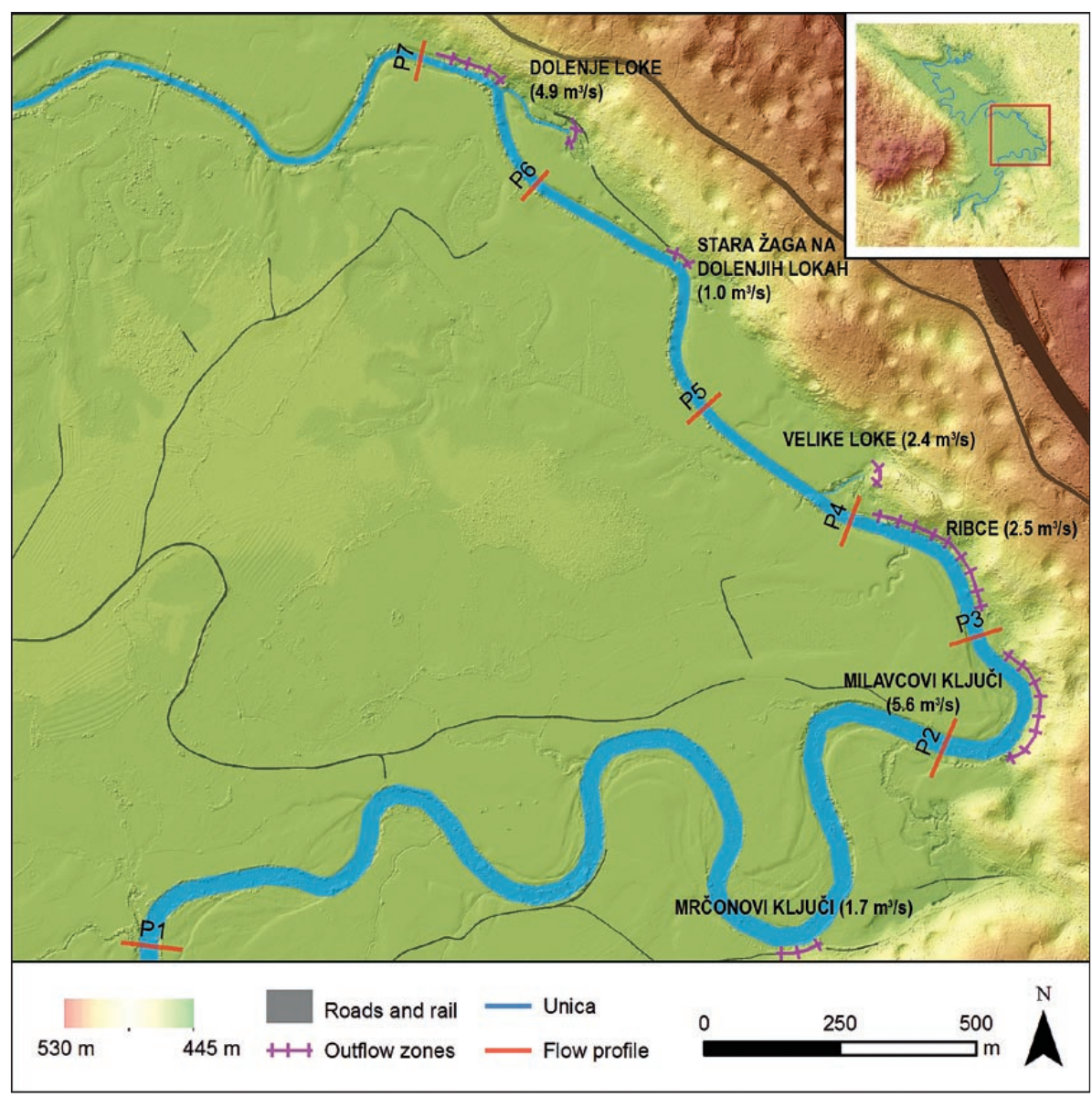

Fig. 9: Reach of Unica along the eastern border of Planinsko Polje with locations of the ADCP profiles, basic characteristics of the outflow zones and outflow rates between each successive profile during the time of measurements (DEM data from ARSO $(2017 b))$

Tab. 1: Measured discharges at two successive profiles, discharge corrections due to flow recession and calculated outflow of the Unica River.

\begin{tabular}{l|c|c|c}
\hline Profile $\left(\mathrm{P}_{\mathrm{i}}\right)$ & $\begin{array}{c}\mathrm{Q}_{\mathrm{i}-1}->\mathrm{Q}_{\mathrm{i}}\left[\mathrm{m}^{3} / \mathrm{s}\right] \\
\text { measured }\end{array}$ & $\begin{array}{c}{\left[\mathrm{m}^{3} / \mathrm{s}\right]} \\
\text { correction }\end{array}$ & $\begin{array}{c}{\left[\mathrm{m}^{3} / \mathrm{s}\right]} \\
\text { outflow }\end{array}$ \\
\hline P1 - P2 & $26.1->25.2$ & 0.8 & $\mathbf{1 . 7}$ \\
\hline P2- P3 & $25.2->19.7$ & 0.1 & $\mathbf{5 . 6}$ \\
\hline P3 - P4 & $19.7->17.5$ & 0.3 & $\mathbf{2 . 5}$ \\
\hline P4-P5 & $17.5->15.3$ & 0.3 & $\mathbf{2 . 4}$ \\
\hline P5-P6 & $15.3->14.6$ & 0.3 & $\mathbf{1 . 0}$ \\
\hline P6-P7 & $14.6->9.9$ & 0.2 & $\mathbf{4 . 9}$ \\
\hline Total & & $\mathbf{2 . 0}$ & $\mathbf{1 8 . 1}$ \\
\hline
\end{tabular}

concrete constructions. Despite the long line with many apparent ponors, the outflow was only $2.5 \mathrm{~m}^{3} / \mathrm{s}$, which is considerably less than between $\mathrm{P} 2$ and $\mathrm{P} 3$.

P4 - P5: P4 and P5 are upstream and downstream from the $200 \mathrm{~m}$ long channel, which guides water to the ponor zone "Velike loke" (Fig. 2 \& 7 \& 9). There, the water sinks into numerous openings and fractures with a total outflow of $2.4 \mathrm{~m}^{3} / \mathrm{s}$.
P5 - P6: Along the $500 \mathrm{~m}$ long line between P5 and P6 the river touches the polje's border only at one spot called "Stara žaga", where the water is guided to the reinforced ponor. Otherwise most of the flow is relatively distant from the border. Several blind valleys in alluvium indicate smaller outflows (Fig. 7). The total outflow between $\mathrm{P} 5$ and $\mathrm{P} 6$ was $1 \mathrm{~m}^{3} / \mathrm{s}$.

P6 - P7: There are several important outflow zones between P6 and P7. The most distinct is a $200 \mathrm{~m}$ long channel incised into the alluvium, which drains part of the water into several swallow holes at its terminal part. At the bifurcation between this side channel and the main channel, there is the largest ponor of the polje, about $170 \mathrm{~m}$ long cave "Jama v Dolenjih lokah", whose entrance part is a reinforced concrete channel (Fig. 7). The zone continues for another $150 \mathrm{~m}$ with several evident ponors. The outflow recorded between P6 and P7 was $4.9 \mathrm{~m}^{3} / \mathrm{s}$. After $\mathrm{P} 7$ the river makes a sharp turn and starts to meander over the polje towards its western border (Fig. 1).

The total outflow along the eastern border was $18.1 \mathrm{~m}^{3} / \mathrm{s}$ under the given hydrological conditions. 


\section{DISCUSSION}

Tracing experiments carried out in 1974-1975 have demonstrated that water outflowing from the eastern border of the polje flows towards the Ljubljanica springs (Gospodarič \& Habič 1976). The highest flow velocities were higher than $200 \mathrm{~m} / \mathrm{h}$, indicating a well-developed conduit system. During the tracing tests, the outflows at Milavčevi ključi (P2 - P3), Ribce (which probably included Velike loke, P3 - P5) and Dolenje loke (P6 - P7) were estimated to be $4.94 \mathrm{~m}^{3} / \mathrm{s}, 4.52 \mathrm{~m}^{3} / \mathrm{s}$ and $5.67 \mathrm{~m}^{3} / \mathrm{s}$ respectively. These results are similar to the results presented in this study, however details of the measurements procedure and the hydrological situation are not given in the reference (Gospodarič \& Habič 1976).

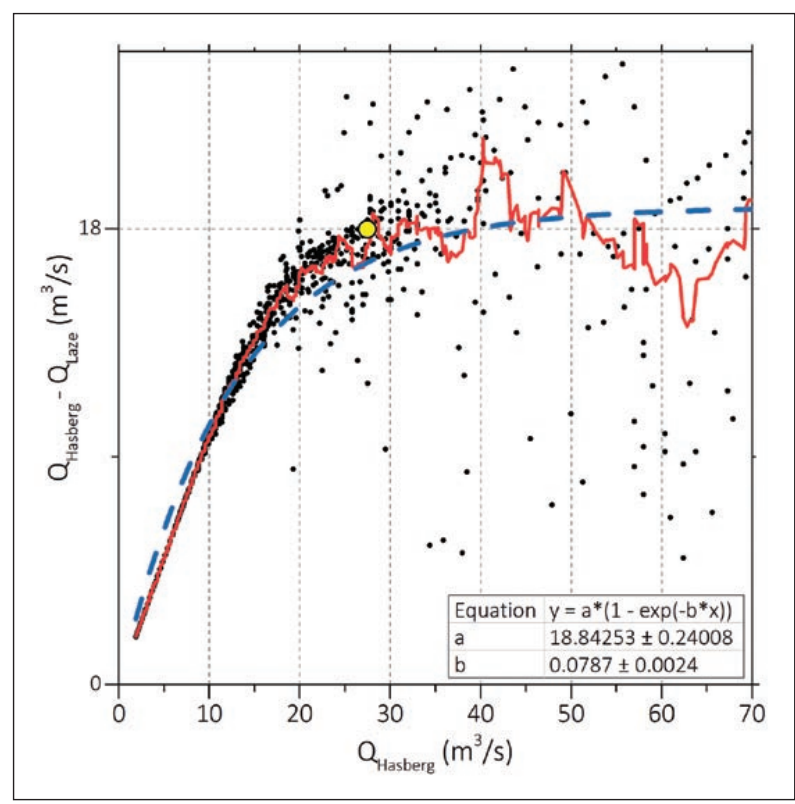

Fig. 10: Scatter plot of daily discharge values at the Hasberg gauging station vs. change of discharge between the Hasberg gauging station and the Laze Bridge gauging station (data range September 1973 - April 1975). The red line presents a moving average $(n=20)$, dashed blue line shows a fit with increasing form of exponential decay model; the parameter values are listed in the table. The yellow dot presents the conditions of ADCP measurements.

During the 1974-1975 tracer field campaign (Gospodarič \& Habič 1976), a supplementary gauging station was operative at the bridge over the Unica River near the village of Laze (Laze Bridge from hereon). Daily discharges from the Hasberg and Laze Bridge stations are available in the hydrological archive of the Ministry of the Environment and Spatial Planning for the period between September 1973 and April 1975 (ARSO 2017a). These two stations are located upstream and down- stream from the eastern line of ponors, so that the data obtained in our study can be directly compared to the old records.

Fig. 10 shows a scattered plot between the discharge at Hasberg and the difference between the discharges at Hasberg and at the Laze Bridge. The plot therefore shows the dependence of outflow through the eastern border on the Unica discharge. Because the outflow increases as the discharge increases, the growth can be approximated with several growth models, e.g. dashed blue line present exponential decay model with its equation and the values given in the plot's table. The data scattering increases as well with the discharge, making the analysis

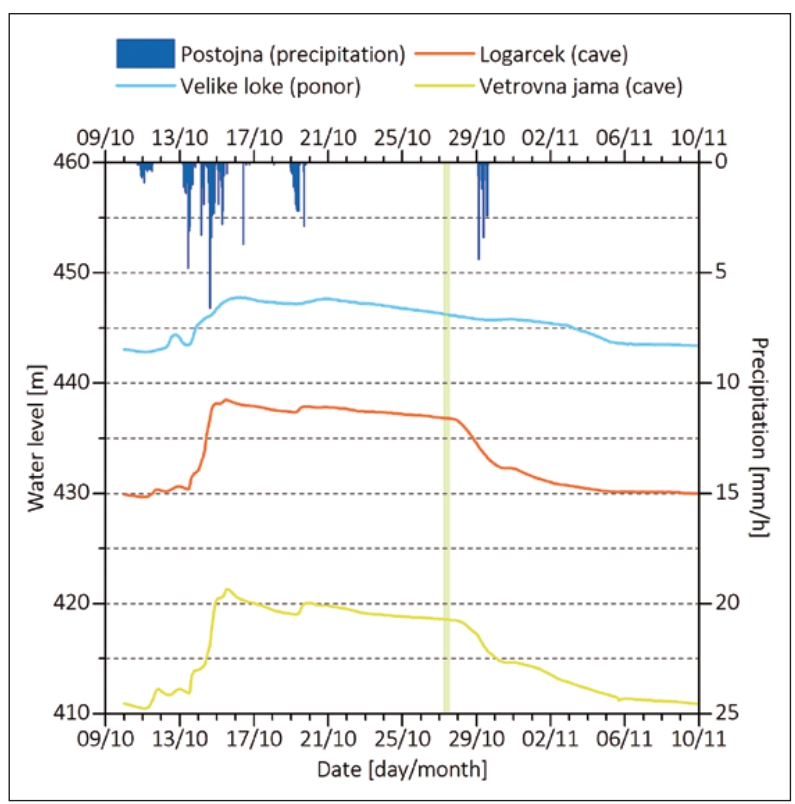

Fig. 11: Level hydrographs (in meters above sea level) in two active caves located in proximity of the polje's eastern border compared to the level hydrograph at the Velike loke outflow zone (P4 - P5). The green line indicates the period of discharge measurements. Hourly precipitation graph is given for the reference.

questionable for discharge larger than a $30 \mathrm{~m}^{3} / \mathrm{s}$ threshold. The scattering might origin from the errors in stagedischarge curves, or due to different timing of daily measurements. In addition, an increase of discharge and flow cross-section might activate additional outflow zones and ponors which would drain more flow into the karst massif. Thus, an increase of outflow simultaneous to an increase of discharge can also be a result of an increasing hydraulic head that the outflow zones are subjected to.

The analysis of the 1973-1975 data indicates that an average outflow for the discharge range between $26 \mathrm{~m}^{3} / \mathrm{s}$ and $28.5 \mathrm{~m}^{3} / \mathrm{s}$ (i.e. similar to the hydrological conditions 
in October $27^{\text {th }}, 2015$ ) was $17.3 \pm 2 \mathrm{~m}^{3} / \mathrm{s}$ (Fig. 10). This value is comparable to the $18.1 \mathrm{~m}^{3} / \mathrm{s}$ value obtained with the ADCP measurements.

In January 2015, automatic measurements of water level and temperatures within most caves with access to water flow between the polje and the springs of Ljubljanica were established. Fig. 11 shows time series of water level between October $10^{\text {th }}$ and November $10^{\text {th }}$ in two caves located in the polje surrounding (see Fig. 1), which are presumably connected to the eastern border outflow zone (see also Gabrovšek and Turk (2010) for a more profound analysis). The level was also continuously recorded at the Velike loke ponor (P4 - P5). Water level hydrographs in both caves are very similar and show a clear hydraulic connection between the two locations. They also show a plateau when Unica discharge surpasses $20 \mathrm{~m}^{3} / \mathrm{s}$. Gabrovšek and Turk (2010) related the plateau to the outflow capacity of the eastern border. The green line on Fig. 11 shows the time of discharge measurements, which is still on the hydrograph plateau. The level at Velike loke shows a similar behaviour, however, the two distinct peaks and recessions are delayed compared to the caves. This might indicate the backward propagation of flood due to flow restriction within the karst massif. However, detailed mechanisms are focus of an ongoing research, which goes beyond the scope of this study.

\section{CONCLUSION}

This work presents the direct measurements of outflow from karst poljes using an ADCP device. Because the outflow is relatively dispersed along lines of intense leakage and several discrete ponors, it cannot be measured directly. However, it can be indirectly estimated based on the decrease of discharge along the reach of the river. To avoid additional corrections as in the case presented here, such measurement should be made in a shortest pe- riod possible or during stable flow conditions. The results presented here can be taken as a good approximation of maximal outflow capacity of the eastern border of the Planinsko Polje. This research is part of a broader study on groundwater dynamics between the Planinsko Polje and the springs of Ljubljanica River. The results will be further implemented in a hydraulic model that is already being developed.

\section{ACKNOWLEDGEMENTS}

The work of M.B. was supported by the Young Researchers Programme of Slovenian Research Agency. The work of F.G. was supported by projects J5-7178 and L1-6731 and programme P6-0119, both financed by the Slovenian Research Agency. The data and the field work pro- vided by the Slovenian Environment Agency are highly appreciated. We thank two anonymous reviewers and Dr. Cyril Mayaud for their valuable comments and suggestions, which led to substantial improvement of the manuscript.

\section{REFERENCES}

ARSO, 2014: Hidrološko poročilo o poplavah v dneh od 8. do 27. februarja 2014.- Ljubljana, Agencija Republike Slovenije za okolje.

ARSO, 2017a: Hydrological archive.- [Online] Available from: http://vode.arso.gov.si/hidarhiv/ [Accessed January $\left.24^{\text {th }} 2017\right]$.
ARSO, 2017b: Lidar data fishnet.- [Online] Available from: http://gis.arso.gov.si/ [Accessed January $24^{\text {th }}$ 2017].

Drole, F., 2015: Rakov Škocjan in Planinsko polje 2014.Proteus, 76, 6, 275-281.

Ford, D.C. \& P.W. Williams, 2007: Karst Hydrogeology and Geomorphology.- John Wiley \& Sons, pp. 562, Chichester. 
Frantar, P. (ed.), 2008: Water balance of Slovenia 19712000.- Ministrstvo za okolje in prostor, Agencija Republike Slovenija za okolje, pp. 119, Ljubljana.

Frantar, P. \& F. Ulaga, 2015: Visoke vode Planinskega polja leta 2014.- Ujma, 29, 66-73.

Gabrovšek, F., Kogovšek, J., Kovačič, G., Petrič, M., Ravbar, N. \& J. Turk, 2010: Recent results of tracer tests in the catchment of the Unica River (SW Slovenia).- Acta Carsologica, 39, 1, 27-37. DOI: http:// dx.doi.org/10.3986/ac.v39i1.110

Gabrovšek, F. \& J. Turk, 2010: Observations of stage and temperature dynamics in the epiphreatic caves within the catchment area of the Ljubljanica river (Slovenia).- Geologia Croatica, 63/2, 187-193. DOI: http://dx.doi.org/104154/gc.2010.16

Gams, I., 2004: Kras v Sloveniji v prostoru in času.- ZRC Publishing, pp. 515, Ljubljana.

Gospodarič, R. \& P. Habič (eds.), 1976: Underground water tracing: Investigations in Slovenia 1972-1975.Institute for Karst Research, pp. 312, Ljubljana.

Jenko, F., 1959: Hidrogeologija in vodno gospodarstvo krasa.- Državna založba Slovenije, pp. 237, Ljubljana.

Kovačič, G. \& N. Ravbar, 2010: Extreme hydrological events in karst areas of Slovenia, the case of the Unica River basin.- Geodinamica Acta, 23, 1-3, 89100. DOI: http://dx.doi.org/10.3166/ga.23.89-100

Krivic, P., Verbovšek, R. \& F. Drobne, 1976: Hidrogeološka karta. 1: 50 000.- In: Gospodarič, R. \& P. Habič (eds.) Underground water tracing: Investigations in Slovenia 1972-1975. Institute for Karst Research, Ljubljana.

Milanović, P., 2004: Water resources engineering in Karst.CRC Press, pp. 328, Boca Raton.

Mohrlock, S.E., 1996: Evaluation of Acoustic Doppler Current Profiler Measurements of River Discharge. Water-Resources Investigations Report 95-4218, U.S. Geological Survey.- [Online] Available from: https://pubs.usgs.gov/wri/wri95-4218/pdf/wri954218.pdf [Accessed 15 ${ }^{\text {th }}$ November 2016].
Mueller, D.S., Wagner, C.R., Rehmel, M.S. \& F. Rainville, 2013: Measuring discharge with acoustic Doppler current profilers from a moving boat.- Techniques and Methods 3-A22, U.S. Geological Survey, pp. 63, Reston, Virginia.- [Online] Available from: http:// pubs.usgs.gov/tm/3a22/pdf/tm3a22_lowres.pdf [Accessed 15 ${ }^{\text {th }}$ November 2016].

Putick, W., 1899: Die hydrologischen Geheimnisse des Karstes und seine unterirdischen Wasserläufe: auf Grundlage der neuesten hydrotechnischen Forschungen.- Himmel und Erde.

Ravnik, D., 1976: Kameninska podlaga Planinskega polja.- Geologija, 19, 291-315.

Stepišnik, U., Ferk, M., Gostinčar, P. \& L. Černuta, 2012: Holocene high floods on the Planina Polje, Classical dinaric karst, Slovenia.- Acta Carsologica, 41, 1, 5-13. DOI: http://dx.doi.org/10.3986/ac.v41i1.44

Stevanović, Z. \& P. Milanović, 2015: Engineering challenges in Karst.- Acta Carsologica, 44/3, 381-399. DOI: http://dx.doi.org/10.3986/ac.v44i3.2963

Šušteršič, F., 2002: Where does Underground Ljubljanica Flow?.- RMZ Materials and Geoenvironment, 49/1, 61-84.

Teledyne Instruments, 2016: RiverRay ADCP, Intelligent River Discharge System, A Revolution in Discharge Measurement.- [Online] Available from: http:// www.teledynemarine.com/Lists/Downloads/riverray_datasheet_hr.pdf [Accessed $15^{\text {th }}$ November 2016].

Trček, R. \& B. Cankar, 2006: Meritve visokovodnih pretokov Slovenskih rek $\mathrm{z}$ ultrazvočnimi merilniki.Ujma, 20, 182-187. 